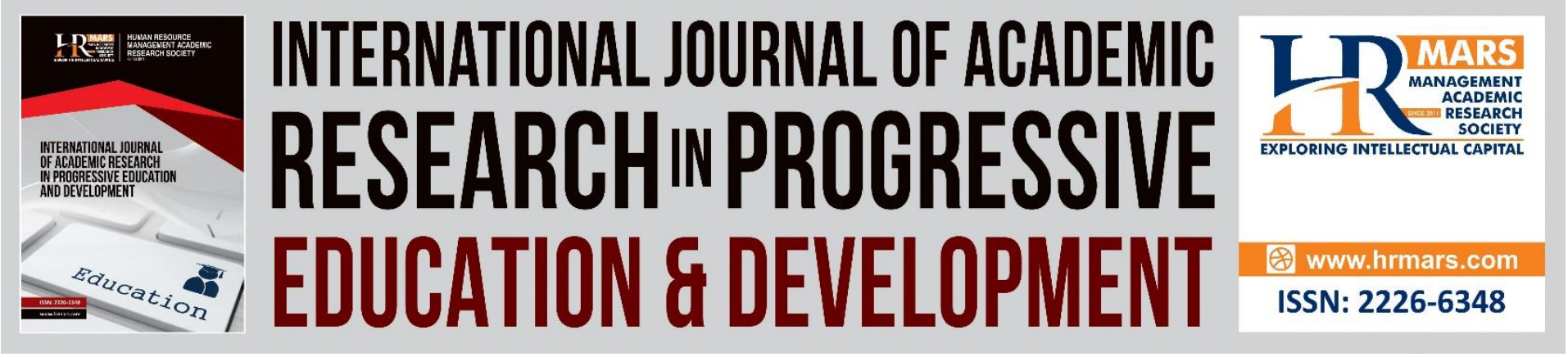

\title{
The Impact of Corporate Social Responsibility (CSR) UITM towards Agriculture B40 Students in Terms of Academic and Employability Performance
}

Wan Zuraida Wan Mohd Zain, Nurain Johar, Aini Japaar, Mazlina Mahdzar, Muhammad Akram Rahman, Ahmad Shahril Azwan Abd Rahim

To Link this Article: http://dx.doi.org/10.6007/IJARPED/v10-i3/10767

DOI:10.6007/IJARPED/v10-i3/10767

Received: 15 June 2021, Revised: 20 July 2021, Accepted: 05 August 2021

Published Online: 28 August 2021

In-Text Citation: (Zain et al., 2021)

To Cite this Article: Zain, W. Z. W. M., Johar, N., Japaar, A., Mahdzar, M., Rahman, M. A., \& Rahim, A. S. A. A. (2021). The Impact of Corporate Social Responsibility (CSR) UITM towards Agriculture B40 Students in Terms of Academic and Employability Performance. International Journal of Academic Research in Progressive Education and Development, 10(3), 660-675.

Copyright: (C) 2021 The Author(s)

Published by Human Resource Management Academic Research Society (www.hrmars.com)

This article is published under the Creative Commons Attribution (CC BY 4.0) license. Anyone may reproduce, distribute, translate and create derivative works of this article (for both commercial and non-commercial purposes), subject to full attribution to the original publication and authors. The full terms of this license may be seen at: http://creativecommons.org/licences/by/4.0/legalcode

Vol. 10(3) 2021, Pg. 660 - 675 


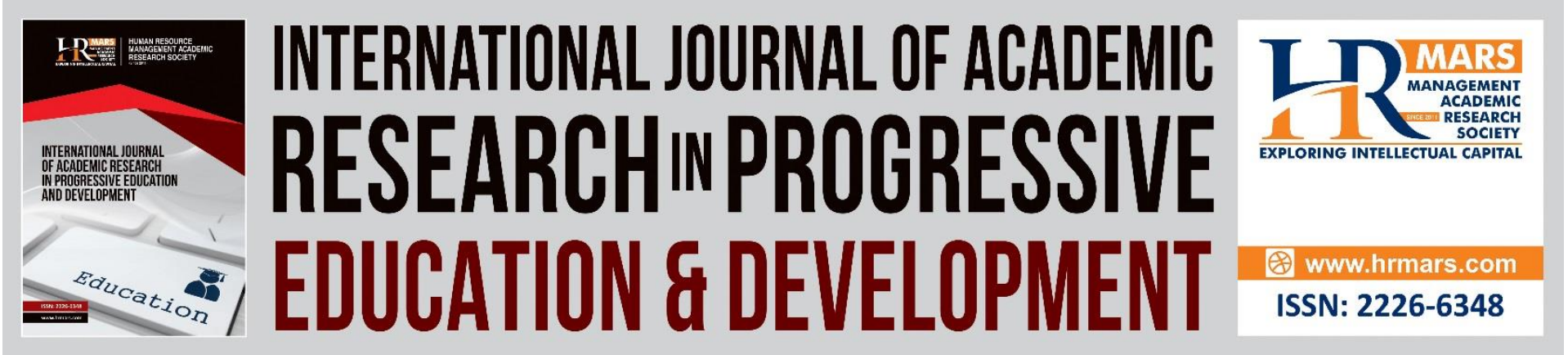

\title{
The Impact of Corporate Social Responsibility (CSR) UITM towards Agriculture B40 Students in Terms of Academic and Employability Performance
}

\author{
Wan Zuraida Wan Mohd Zain ${ }^{1,2}$, Nurain Johar ${ }^{3}$, Aini Japaar, ${ }^{1,4}$, \\ Mazlina Mahdzar ${ }^{1,5}$, Muhammad Akram Rahman', Ahmad \\ Shahril Azwan Abd Rahim ${ }^{1}$ \\ ${ }_{1}^{1}$ Pejabat Program Pra Pendidikan Tinggi, Universiti Teknologi MARA, 40450 Shah Alam, \\ Selangor, Malaysia, ${ }^{2}$ Faculty of Plantation and Agrotechnology, Universiti Teknologi MARA, \\ Malacca branch, Jasin Campus, 77300 Merlimau, Malacca, Malaysia, ${ }^{3}$ Faculty of Applied \\ Science, Universiti Teknologi MARA, Mukah branch, Sarawak Campus, 96400 Mukah, \\ Sarawak, Malaysia, ${ }^{4}$ Faculty of Architecture, Planning and Surveying, Universiti Teknologi \\ MARA, 40450 Shah Alam, Selangor, Malaysia, ${ }^{5}$ Faculty of Hotel and Tourism Management, \\ Universiti Teknologi MARA, Puncak Alam Campus, 42300, Selangor, Malaysia
}

\begin{abstract}
Universiti Teknologi MARA (UiTM) has always acknowledged the needs to provide the opportunities get a quality education at the tertiary level. One of the many initiatives is its corporate social responsibility (CSR) programme which is established to give financial support to $B 40$ youth to pursue their studies through a pre-diploma programme. This CSR programme has helped 40,836 B40 pre-diploma students from the year of 2010 until 2018. Thus, a study has been conducted to investigate the overall academic performance and employability of the pre-diploma programme students who pursued their study in Faculty of Plantation and Agrotechnology. This study provides an overview of the achievements of institutional efforts in helping underprivileged students in preparing them for real work scenarios in agricultural sector with a good level of education. Primary data have been obtained from databases which handled by the UiTM Transformation Unit. Numerical analysis of the employability data was obtained through questionnaires and surveys from Skim Kajian Pengesanan Graduan (SKPG). All the data have been screened, cleaned, and coded accordingly using Microsoft Excel to find the connections and relationships. Descriptive statistics from the findings revealed that 81 , 32 and two pre-diploma students successfully graduate their studies to diploma, bachelor's and master degree respectively. $48 \%$ of the graduates are currently employed mostly in the private sector with the 'fresh graduates' qualification offered salaries between RM1,000 RM1,800. In future work, further research can be done on how these pre-diploma students of low-income families can change the socioeconomics of their families as agriculture sector
\end{abstract}


has been providing employment opportunities for communities across the region and it is a key factor for development in Malaysia. This could be a continuation of the recent work as its indicate that the CSR programme has met its objective to change the destiny of the nation's children.

\section{Introduction}

Corporate social responsibility (CSR) is not new to universities that have long worked to benefit society by educating new generations of people as well as by engaging in community service (Dima, 2013). Universities can provide the platform for community services as universities build bridges internationally, serve as national gateways for the sharing and dissemination of knowledge, and influence society through the ideas and values shaped by the humanities and liberal arts (Plantan, 2013).

In a study about CSR in Malaysia, Mohamed Zain and Mohammad mentioned that the most popular theme was human resources, and the most popular sub-themes were education, participation in sports, culture, and philanthropy (Zain et al., 2007). Moreover, research by Ismail stated that education-related initiatives were the most dominant type of CSR programme (Ismail et al., 2015).

As one of the largest universities in Malaysia, UiTM believes that giving students a second chance is the best approach. UiTM also plays a vital role in education for human capital development and economic growth. According to Kuh, the experience gained by first-year university students is vital to establishing baseline knowledge, a positive attitude, selfconfidence, and a commitment to study (Kuh, 2001).

Thus, in 2010, UiTM initiated a CSR programme named "Mengubah Destini Anak Bangsa (MDAB)" (translated as "Changing the Destiny of the Nation's Youth" Programme). This special programme is self-funded through a voluntary salary deduction by the UiTM staff members itself, as well as some corporate contributions (Darby, 2013). The objective of the programme is to allow Bumiputera students with underqualified entry requirements of Malaysian Certificate of Education (Sijil Pelajaran Malaysia - SPM) to further their studies in higher education. Normally the students with poor academic performance on SPM result has a lower chance to being offered for diploma study. Thus, this special programme was established to help this student to further their study at higher level. The selected students were fully sponsored in terms of tuition and hostel fees and receive bi-weekly living allowances, provided they were from B40 families with a monthly gross income of less than RM4,000 (Jaapar et al., 2021).

The objective of this tracer study is to investigate the impact of this CSR programme on these B40 student in terms of academic performance and employability. The research focuses on the Faculty of Plantation and Agrotechnology (FPA) students who enrolled in the programme between 2010-2018.

\section{Methodology}

This study employed a quantitative procedure. Data collection involved a process of obtaining primary data from the databases of Students Information System Management, which is administered by the Centre for Strategic Planning and Information (CSPI), UiTM Shah Alam. There were 40,836 records of pre-diploma students who enrolled at 13 UiTM Branches for PPT programmes between 2010 and 2018 have been obtained from the databases. The academic performance and employability for all Faculty of Plantation and Agrotechnology 
(FPA) students who had enrolled in the MDAB programme for the year 2010 to 2018 were analysed in detail using Microsoft Excel. The employability data was obtained from Skim Kajian Pengesanan Graduan (SKPG).

\section{Result and Discussion}

Currently, the CSR PPT programme offers two tracks: Pre-Commerce and Pre-Science. The Pre-Science and Pre-Commerce is a one to two semester bridging programme with the objective to help the students academically, especially in the science and mathematics subjects, before they are accepted into any science and technological-based Diploma course in any of the UiTM campuses throughout the country. Currently, thirteen state campuses are working closely with the MDAB office in UiTM Shah Alam, which now known as the Pejabat Program Pra Pendidikan Tinggi (PPT). They are important administrators that manage approximately 3000 students per year. Out of thirteen, four campuses run pre-diploma courses in science; twelve campuses run the pre-diploma courses in commerce and four campuses run both tracks.

Table 1 shows the general requirements for both tracks. These tracks prepare students to begin their studies at the diploma level with the condition that they obtain at least a Cumulative Grade Point Average (CGPA) of 3.00 for Pre-Science and 2.00 for Pre-Commerce and later continue pursuing their education to a higher level. If the students failed to meet these goals, they would have to continue the programme for another semester.

Table 1. Basic Entry Requirements to Apply PPT Programme.

\begin{tabular}{|c|l|}
\hline Pre- Diploma Commerce & Pre - Diploma Science \\
\hline \multirow{2}{*}{$\begin{array}{l}\text { Passed in Mathematics/ } \\
\text { Additional Mathematics }\end{array}$} & $\begin{array}{l}\text { Credit in Mathematics or } \\
\text { Additional Mathematics }\end{array}$ \\
& $\begin{array}{l}\text { Passed in any of these Science } \\
\text { Subjects (Physics, Chemistry, } \\
\text { Biology, Additional Science) }\end{array}$ \\
\hline - Bumiputera* \\
- Malaysian citizens aged 16 and above \\
- PPM qualification with 3 credits including Bahasa Melayu \\
- Passed in History (implemented since 2013) \\
*Bumiputera are Malays, Orang Asli, and Local People of Sabah and \\
Sarawak
\end{tabular}

From the year 2010-2018, 40,836 students had registered the Pre-Diploma study level. Most of the students at $88.62 \%$ enrolled in the Pre-Commerce track while the remaining $11.38 \%$ enrolled in Pre-Science track. From a total number of 40,836 students undergoing the pre-diploma programme 40,194 students had successfully passed this programme which is $98 \%$ success rate as can be seen in Table 2 .

Table 2 also shown that from 2010 to 2014, approximately about 6,000 students enrolled in the programme each year. However, starting the year 2015 until 2018, the number of students reduced significantly as approximately around 3,000 students enrolled in this programme. This is because starting in 2016 until now, UiTM has set the total student intake to a maximum of 3000 students per year due to several factors such as the ability of human capital, working staff and considering the available facilities at the branch campus to cater for 
students' hostel placement, classrooms, laboratory etc. The data in Table 2 shows that the percentage of students that pass has been steadily increasing over time as in the years 2017 and 2018 , more than $90 \%$ of the student had passed this programme. This positive trend can be related to the continuous effort by the lecturer to give the best in the process of teaching and learning. This number also shows that B40 students from Pre-Diploma level have successfully achieved their first stage of advancement in their studies with the help of this CSR programme under PPT.

Table 2. Students Pre-Diploma Achievements 2010-2018.

\begin{tabular}{lll}
\hline Session/Years & $\begin{array}{l}\text { Pass/Graduated } \\
(\%)\end{array}$ & No. of Students \\
\hline 2010 & 79 & 6382 \\
2011 & 85 & 6457 \\
2012 & 76 & 5849 \\
2013 & 88 & 6109 \\
2014 & 89 & 5695 \\
2015 & 88 & 2769 \\
2016 & 89 & 2614 \\
2017 & 91 & 2289 \\
2018 & 91 & 2030 \\
\hline Total & & 40,194 \\
\hline
\end{tabular}

Figure 1 shows that 17 faculties have been selected by the Pre-Commerce students to pursue their diploma study level. Among that, the Faculty of Business Management (FPP) has been the top faculty as it has been chosen by the 15,143 students compared to other faculties. Pre-Science student has a wide range of field to continue their diploma study level as Figure 2 shows that there are 21 faculties has been selected as compared to 17 faculties by PreCommerce students. Faculty of Applied Sciences (FSG) becomes the top choice as the data indicates that 1105 students chose to further their study in this faculty.

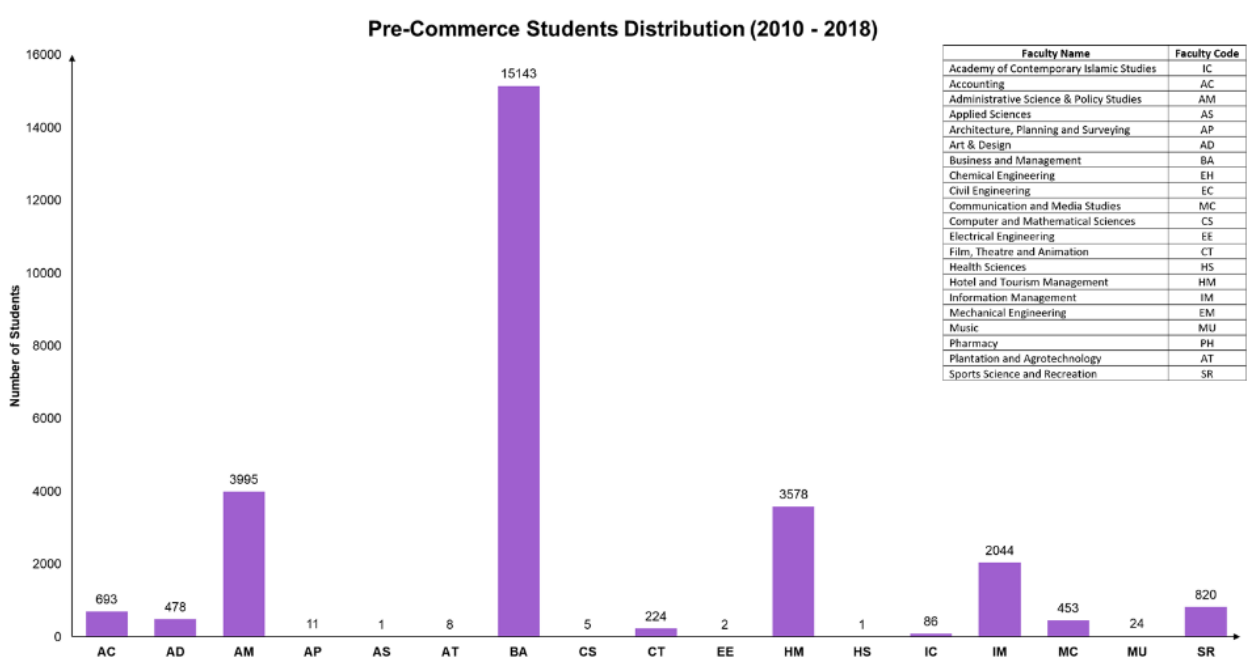

Figure 1. Faculty's Distribution chosen by Pre-Commerce Students from 2010-2018 


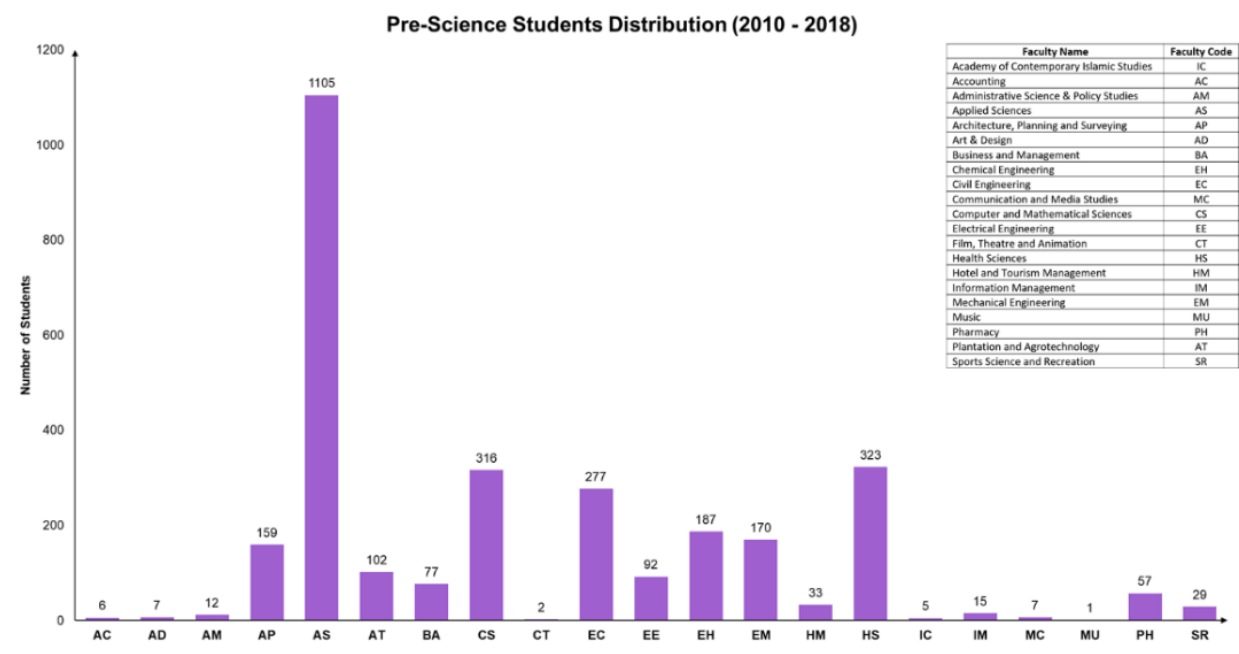

Figure 2. Faculty's Distribution chosen by Pre-Science Students from 2010-2018

Figure 2 also shows that 102 of the Pre-Science students also chose Faculty of Plantation and Agrotechnology (FPA) to pursue their diploma study. As this number is quite considerate, this research will be focused on FPA as a pilot study. The tracer study has been done to reach out FPA student and we successfully contain 89 students from a total 102 students.

Most of the FPA students from all levels (diploma, degree and master's) are from the Pre-Science intake as can be seen in Figure 3. However, there is still quite a number from PreCommerce students whose pursue their study at higher level in FPA. As for Pre-Science students during their 6 months to 1 year study, the students are required to pass sciences subject which are chemistry, physics, mathematics and biology or advanced mathematics as well to get a minimum CGPA 3.00 to pursue their study in FPA program. Meanwhile for PreCommerce students, their academic performance during Pre-Diploma level and SPM results (science stream subjects) need to comply the minimum entry requirement for FPAs programme. This requirement is needed to ensure that students have the basic understanding on agriculture studies when they pursue the FPAs programme. As Pre-Science students are mostly from the B40 youth generation, it shows that they prefer to further their highest level of study in the field of agriculture. 
FPA Students Record Based on Pre-Science and Pre-Commerce Intake

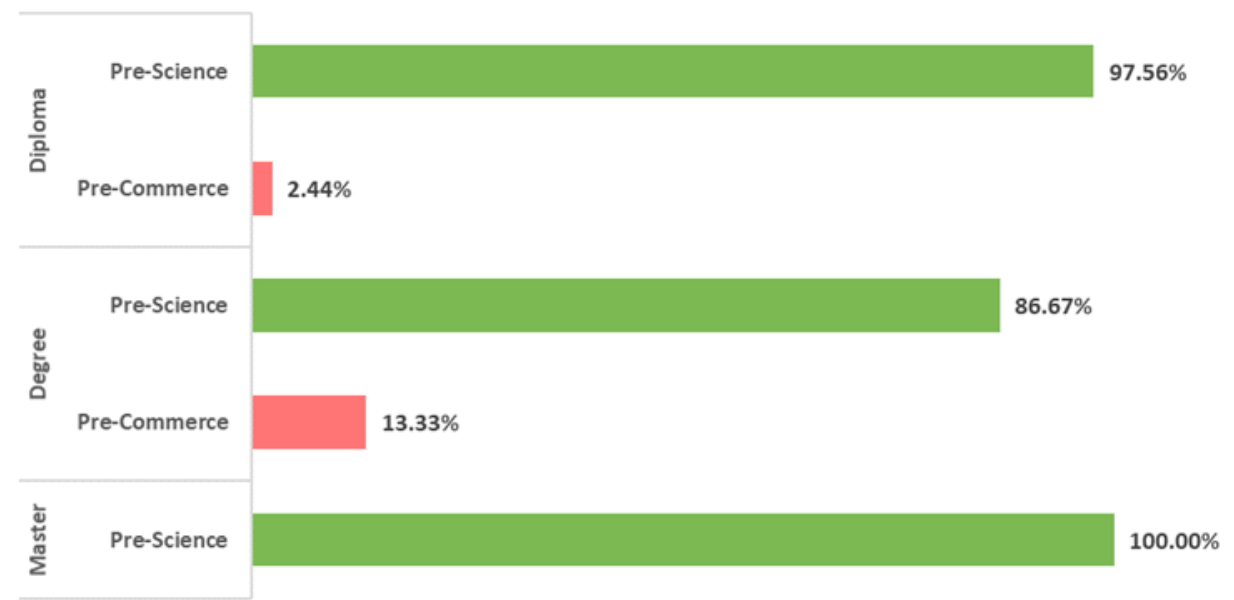

Figure 3. FPA students record based on Pre-Science and Pre- Commerce intake

Figure 4 shows that out of the 40,836 Pre-Diploma students, $75 \%$ of them pursued a diploma in UiTM. Of those 30,825 students, $0.27 \%$ chose to pursue their studies within the Faculty of Plantation and Agrotechnology, $0.10 \%$ pursued a degree in FPA. Most of the students pursuing an FPA degree majority came from the FPA diploma students while the rest were students that had pursued other diplomas. Two students enrolled in a Master FPA programme and are now awaiting their convocation (data gained from BTU).

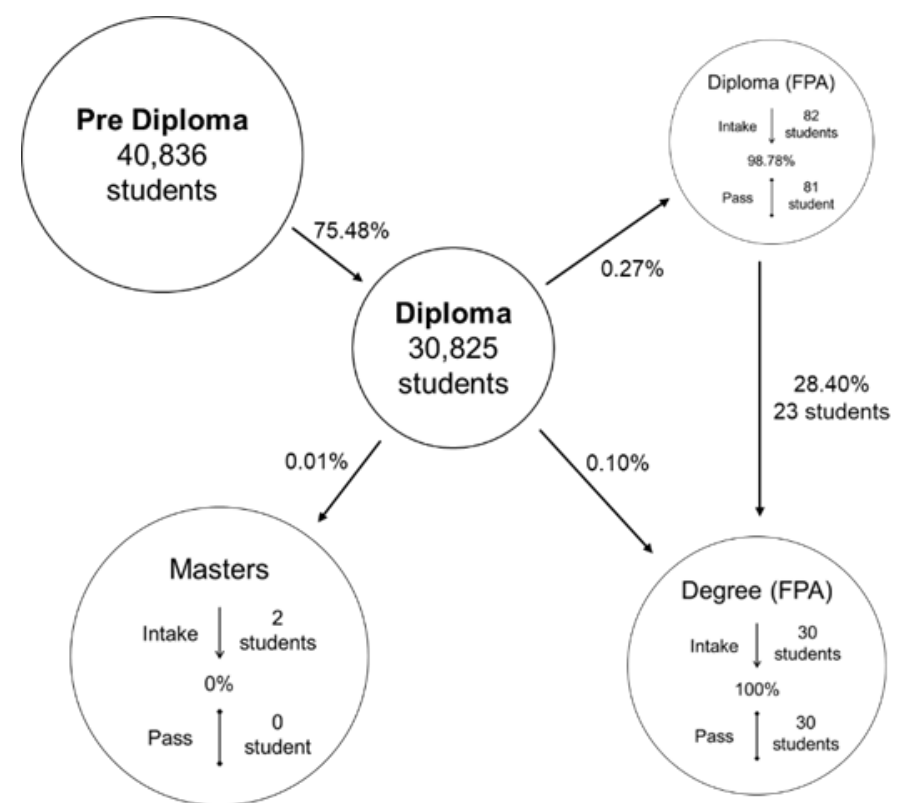

Figure 4. Tracer Study of Faculty Plantation and Agrotechnology Students from CSR PPT Programme 2010-2018

From 2010-2018, the tracer study found that two diploma programmes and twodegree programmes offered by FPA of UiTM has been chosen by the Pre-Diploma students. Table 3 shows that the diploma programmes chosen were AT110 (Diploma in Planting 
Industry Management) and AT117 (Diploma in Aquaculture). The degree programmes chosen were AT220 (Bachelor of Science (Hons) in Plantation Technology and Management) and AT232 (Bachelor of Science (Hons) in Agrotechnology (Horticulture Technology)).

Table 3. FPAs Programme chosen by Pre-Diploma Students

\begin{tabular}{|c|c|c|}
\hline Code Programme & Name of Programme & Campus \\
\hline \multicolumn{3}{|l|}{ Diploma } \\
\hline AT110 & $\begin{array}{l}\text { Diploma in Planting Industry } \\
\text { Management }\end{array}$ & Jasin, Melaka \\
\hline AT117 & Diploma in Aquaculture & Mukah, Sarawak \\
\hline \multicolumn{3}{|l|}{ Degree } \\
\hline AT220 & $\begin{array}{l}\text { Bachelor of Science (Hons) in } \\
\text { Plantation Technology and } \\
\text { Management }\end{array}$ & Jasin, Melaka \\
\hline AT232 & $\begin{array}{l}\text { Bachelor of Science (Hons) in } \\
\text { Agrotechnology (Horticulture } \\
\text { Technology) }\end{array}$ & Arau, Perlis \\
\hline
\end{tabular}

These two diploma programmes are designed to equip students with the essential knowledge for establishing and managing a plantation and aquaculture. At the degree level, the programmes emphasize the various aspects of Production Technology, Management, and Information Technology needed by the agricultural and plantation sectors. As part of the programme academic plan, students will be required to undergo industrial attachment to gain managerial skills in the plantation industry.

Agriculture has been the simplest way of life within the geographical zone for thousands of years, feeding families and providing employment opportunities for communities across the region. Agriculture has become one of the key factors for development in Malaysia. In the Eight Malaysia Plan and the Ninth Malaysian Plan, the agricultural sector has recorded encouraging growth. Moreover, in the Ninth Malaysian Plan, agriculture is expected to be the third highest income generator for the country (Hassan et al., 2010). Many people have taken agriculture for granted due to lack of agricultural knowledge (Hassan et al., 2010). This lack of knowledge has created a stereotype about "farming" and "farmers". Younger people are said to view the act of farming as "hard, boring, physical labor" (Glassman, 2006). In order to increase the youth's interest in agriculture field, educators must include parents, school personnel, and policy makers in the educational process (Musa et al., 2020).

According to (Oduro-ofori et al., 2014), education plays an important role in agriculture, as lack of education or education below secondary level tends to lead to literacy problems. The importance of agriculture is not only to supply adequate food but also to generate income (Aliber, 2005). Accordingly, the agricultural sector has been reporting a significant profit in Malaysia from 2009 to 2013 (Noraniza, 2016). This indicates a good growth within the industry even through it is on a relatively small scale. Most countries around the world have highlighted the importance of this sector to support household consumption and to improve their welfare (Sibhatu et al., 2016). 
Agriculture encompasses a broad field which include livestock, crop production, aquaculture, and various downstream industries. Commercial agriculture refers to agricultural activities encompassing private sector plantations involving rubber and oil palm cultivation, smallholder farms like cocoa and pepper, and big commercial growers of fruits and vegetable crops (Muhammad et al., 2013).

Youth unemployment has been on the agenda of the International Labour Organization (ILO) since 1935, and one of its Sustainable Development Goals (SDG) is to promote continuous, inclusive. and sustainable economic growth, with full and productive employment and decent work for all (Nations, 2015). One of the proposed solutions was to interest more young people in the agricultural sector (Organization, 2015). The ILO supports this proposal because the demand for food will increase in tandem with the growing world population and thus create more jobs across the entire value chain.

The B40 group was selected as a focus of Rancangan Malaysia 11 2016-2020 (RMK-11, the Eleventh Malaysia Plan). Through RMK-11, the government used education as one of the major factors in increasing the income of B40 households and ultimately narrowing the socioeconomic gap (Sani et al., 2020). Higher education institution and skills training institutes were encouraged to allocate more seats and allowing admission by special allocation for B40 students to ensure their access to higher education is secured (Sani et al., 2018).

Figure 5 shows that the majority of the FPA students that enrolled in the PPT programme came from a family with a household income below RM 4000 . B40 or known as Bottom 40 is the term used to refer to the lowest income group in Malaysia. Comprising $40 \%$ of the population in Malaysia, the B40 group's average household income is below RM 3860.00. The statistics of FPAs PPT programme indicate that $36 \%$ of them earn a gross income between RM 1000 to RM 1999.99, 32\% gross income between RM 500 to RM 999.99, 15\% with RM 1 to RM 499, 3\% RM 3000 to RM 3999 and 2\% with no income. The $7 \%$ of students with a family income above RM4000 represent students that gained special admission as orang asli, athletes, and UiTM staff special programmes. Since this study aims to analyse the B40 students, their information will be considered as irrelevant.

This indicates that the family social income played a significant role in motivating the students to further study at higher level. The B40 students has a clear determination to change their economic position. Starting at the year 2010, PPT has done a significant effort to reach out to the $B 40$ student to give them a chance to enrol this special CSR programme. Until now, the PPT's goal of reaching their target market has been achieved as many B40 students has successfully completed the Pre-Diploma study. 
Parents' Income (2010-2018)

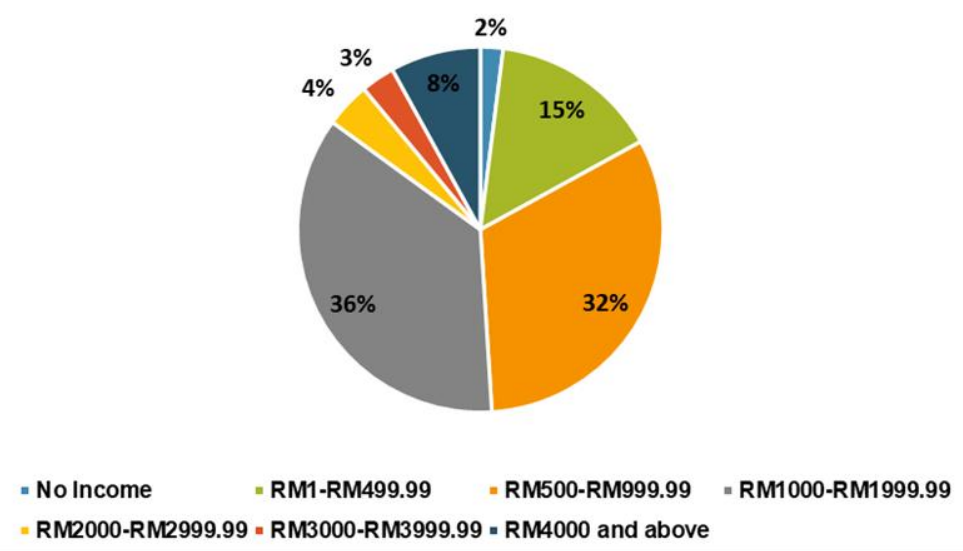

Figure 5. FPA Students Parents' Monthly Gross Income

Figure 6 shows that from a total of 89 students taking part in the four programmes in the Faculty of Plantation and Agrotechnology, the latest survey shows 43 students were employed, 20 were not yet employed, 8 were furthering their studies, 12 were still completing the survey, and 6 did not participate in the survey.

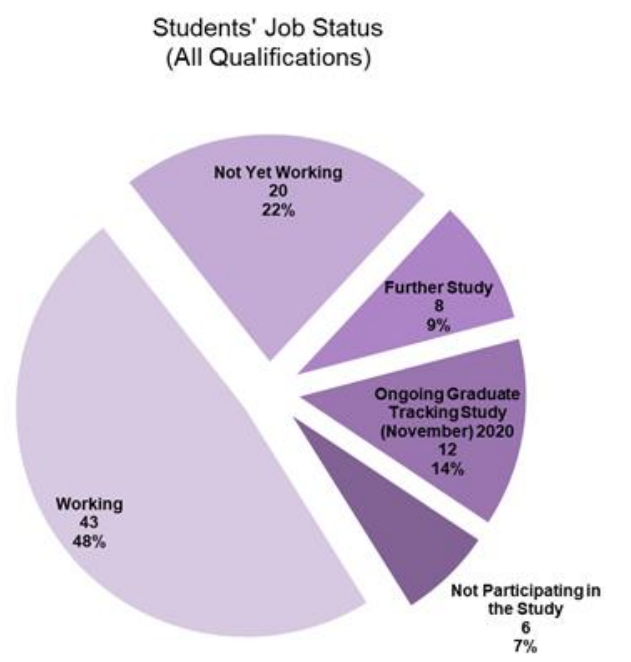

Figure 6. Students Job Status for All Qualification

Graduates are an important asset of a country because they are the ones who will work as a skilled workforce in various key fields and industries to continue the country's economic development. The government has taken several initiatives through the Ministry of Higher Education to give prominence to agricultural education at the tertiary level. The objectives are to train youths, especially graduates, to engage full-time in the agricultural sector and become successful workers and entrepreneurs in the industry. As such, the government has taken steps to produce greater numbers of agriculture graduates to meet the demand of the expected increase in the workforce in the plantation industry and commercial agriculture. 
Employment opportunities for graduates in this field are not difficult to obtain because there are many job opportunities offered in the government sector as well as the private sector. Graduates can also choose to work on their own as farmers or entrepreneurs as the skills and theory has been provided and learned during their study. This is supported by the data shown in Figure 7 as most of the graduates from the FPA are employed by companies in the private sector rather than the government sector and most of them are working for local companies.

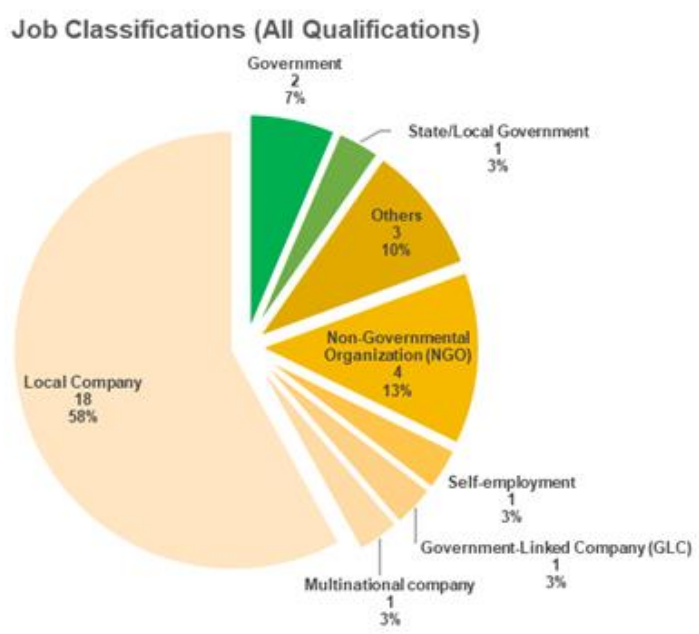

Figure 7. Job Classification for All Qualifications

Figure 8 shows most of the FPA graduates earn a salary between RM 1000 and RM 1500. This range is considered normal for fresh graduate qualification. Median salary for diploma is between RM 1000-1500 while for Degree is RM 1500. Thus, it can be concluded that, the greater the qualifications of the graduates, the higher their salary. This CSR programme by the PPT has proven to increase the quality of life for the B40 students by giving them the opportunity to continue their education and advance on their career path.
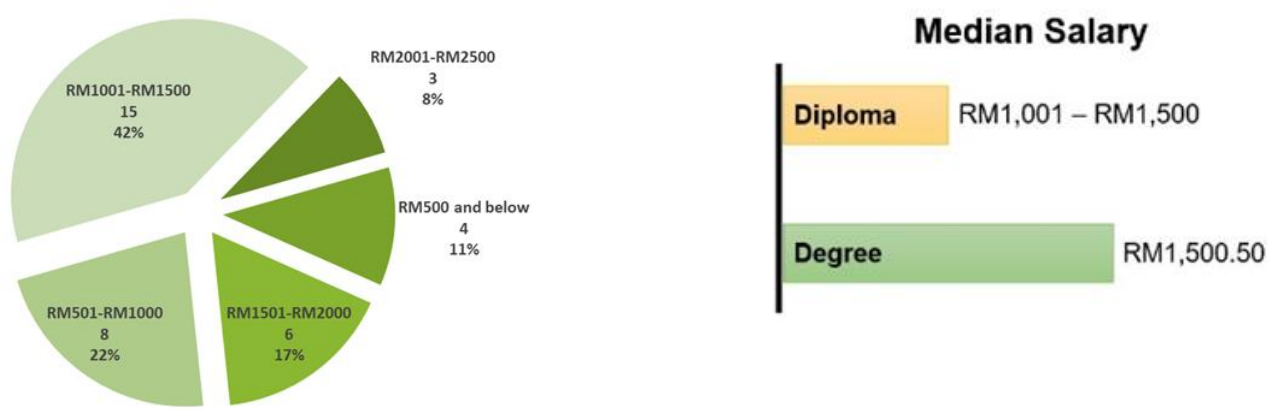

Figure 8. FPA Students Parents' Monthly Gross Income 
In Malaysia, employers are looking for candidates who can cope with the rapid changes in technology and possess adaptable skills (Chong et al., 2014). Candidates who did not receive proper training at an institution of higher learning are regarded as less capable of adapting themselves to the fast changes of the working world (Deborah, 2004). This proves that higher academic qualifications are important when students apply for jobs. Candidates without sufficient academic qualifications earned less compared to their more qualified counterparts.

There are many factors that contribute to the employability of graduates. One of the core functions of the academic curriculum of this programme is to create competent students with a more holistic understanding of working in the real world. In line with this, the Faculty of Plantation and agrotechnology added Industrial training to the syllabus, so for 14 weeks, the students would be attached to multiple industries. In addition, this industrial training is a platform for the companies in the plantation and commercial agriculture sector to find and recruit competent graduates. Field work is also in the academic curriculum and was seen as a positive feature for agriculture students as they felt the activities and field trips in commercial agricultural farms were a fun way to learn and a good opportunity for them. A survey conducted on agriculture students in a few public universities stated that about $89.0 \%$, feel excited to do the job or visit the farms again if given a chance (Muhammad et al., 2013).

Activities and programmes like this are one example of the efforts of the lecturers to conduct active learning and teaching outside the campus, and it involved a student-centred learning approach. Through these activities, the strengthening of soft skills such as communication skills, critical thinking and problem solving, entrepreneurship, ethics and professional morality, leadership and teamwork can be done and have an impact on the capabilities of the students. Thus, the courses in the FPA's academic programme have adopted the learning through field trips so that students are more exposed to real-world experience rather learning in the classroom and the laboratory alone.

Figure 9 shows the CGPA of PPT students that graduates from the FPA programme. On average the FPA's diploma students graduated with a CGPA of 2.95, degree students with 3.15 , and master students with 3.24 respectively. This indicates that students have shown an improvement in CGPA achievement when furthering their studies to higher levels starting with diploma up to master's.

Meanwhile Figure 10 shows the correlation between students' salaries and their CGPA. The graph shows the increase in salary in line with academic qualifications. Generally, students with a degree qualification earn higher salaries than diploma graduate students. This proves that with the knowledge learned and the experience gained during their studies, has prepare themselves to obtain a stable career which can change the socio-economic level of individuals and families. Suicidology states that positive environments in families, peers, schools, and communities are essential in helping and nurturing the cognitive development and providing for the needs of academically gifted students (Margaret et al., 2008). 
INTERNATIONAL JOURNAL OF ACADEMIC RESEARCH IN PROGRESSIVE EDUCATION AND DEVELOPMENT

Vol. 10, No. 3, 2021, E-ISSN: 2226-6348 @ 2021 HRMARS

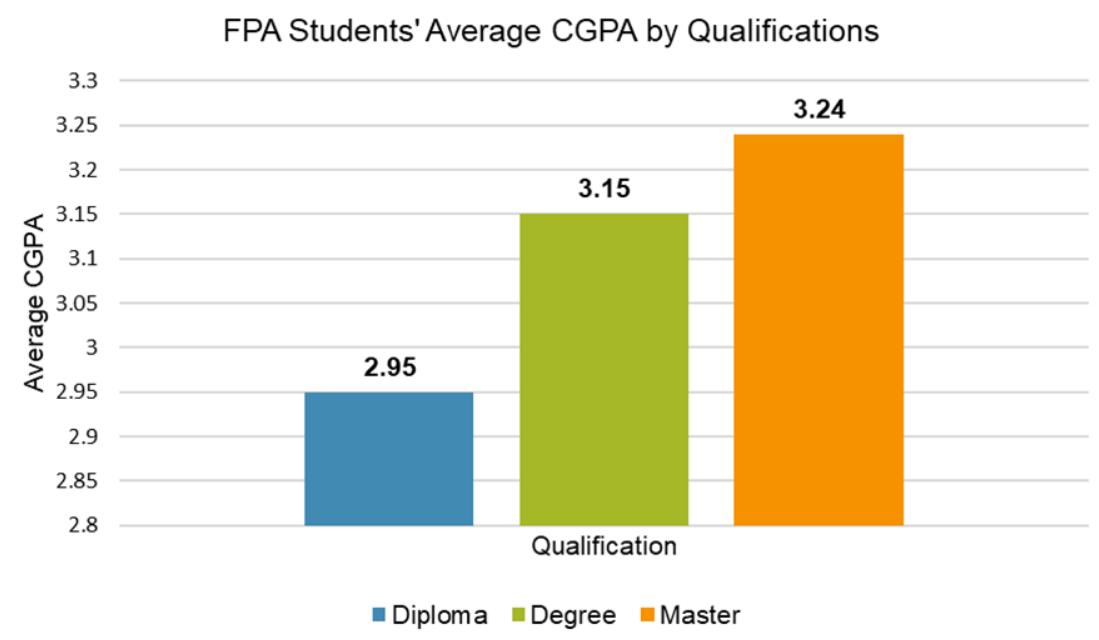

Figure 9. FPA students average CGPA by Qualifications

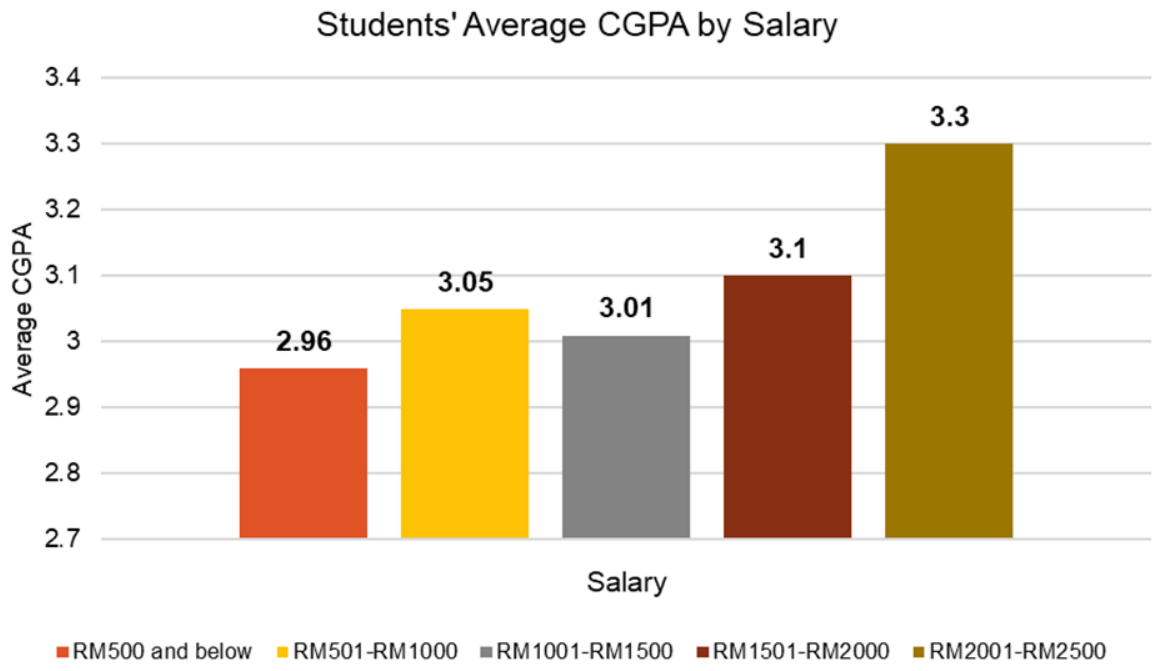

Figure 10. Students average CGPA by Salary

Figure 11 shows the correlation between students' CGPA and Job Status for two qualifications (Diploma and Degree) in the FPA's programme. The employed graduates (36\%) have an average CGPA of 3.04. The unemployed graduates (16\%) have an average CGPA of 2.83 and those graduates that planned to further their studies at master level had an average CGPA of 3.02 . 


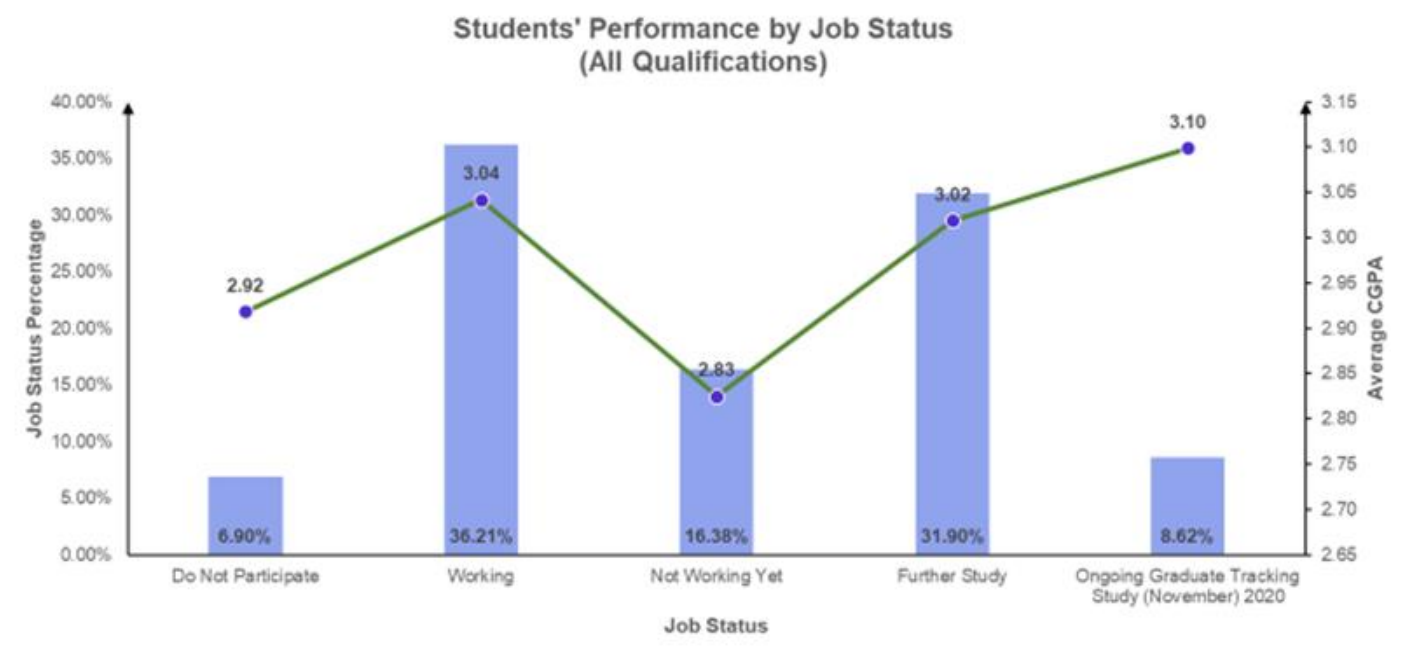

Figure 11. Students CGPA and Job Status for Diploma and Degree Qualification

From this tracer study, it shows that education played a significant role in the career path of the graduates especially in terms of employability. This study indicated that the CSR programme by PPT has met its objectives by providing opportunities to the B40 students. The study also shows that the students themselves have high determination and this is proven when they are able to match the ability of other outstanding students when given a second chance during the pre-diploma study. According to Pan and Lee, high academic qualifications provide confidence and motivation for individuals to confront various challenges they would come across when looking for a job (Pan et al., 2011). In addition, according to Pinto and Ramalheira, individuals with higher academic qualifications are better prepared to find work due to the mastery of their educational and vocational training materials (Pinto et al., 2017). The results of research conducted by McKinney show that a lack of academic qualifications limited employment opportunities and decreased the range of potential salaries (McKinney, 2003). Further research also found that low academic achievement makes the selection process harder. This is supported by the results of Pinto and Ramalheira's which found that a lack of academic qualifications led individuals to obtain jobs that sometimes did not match their desires, meaning there were fewer opportunities for them to choose from (Pinto et al., 2017).

According to Dacre Pool and Sewell, individuals with high levels of academic achievement will motivate themselves to increase their employability by developing their skills and knowledge (Pool et al., 2007). Research conducted by Surridge shows that individuals lacking academic qualifications tend to be hesitant when choosing and specifying their jobs (Surridge, 2009). This is in line with the opinion of Omar, Bakar, and Mat Rashid who revealed that a lack of knowledge and capabilities could hinder an individual's ability to gain employment (Omar et al., 2012).

\section{Conclusion}

The findings of this study prove that the UITM PPT remedial programme has successfully met its objectives of giving opportunities to the students from B40 families by improving their economic position through education on agriculture. The study clearly show that education played an important role in increasing the employability of the students, allowing them to 
raise themselves above the poverty line and the B40 economic category. UiTM believes that students who study in a more conducive environment and with the appropriate financial aid will help them to overcome their academic and learning barriers. With a competitive environment and challenging economic conditions, the academic achievement of these B40 students' needs to be emphasized, so that they can change their lives for the better.

\section{References}

Aliber, M. (2005). Synthesis and conclusions. In Trends and policy challenges in the rural economy: four provincial case studies. Pretoria: Human Sciences Research Council.

Chong, C., Lin, L., Chuen, L., \& Yan, T. (2014). A Study On Factors Influencing Students' Intention To Pursue Higher Education. Kuala Lumpur: Universiti Tunku Abdul Rahman.

Dacre Pool, L., \& Sewell, P. (2007). The key to employability: Developing a practical model of graduate employability. Education Training, 49(4), 277-289.

Darby, Y. S. (2013). Students Get another Chance at Higher Education through Yayasan Sime Darby's Sponsorship of UiTM's MDAB Programme. Retrieved from http://www.yayasansimedarby.com/

Deborah, V. (2004). Access to Higher Education: A Challenge to Social Work Educators. Journal of Social Work Education, 4(2), 179-184.

Dima, A. M., Vasilache, S., Ghinea, V., \& Agoston, S. (2013). A model of academic social responsibility. Transylvanian Review of Administrative Sciences, 38, 23-43.

Glassman, R., Elliot, J., \& Knight, J. (2006). Interactive Agricultural Experiences of 4TH Grade Students in the Arid Southwest: An Examination of the Impact of Hands-on Learning Experiences as a Component of Agriculture in the Classroom Curriculum.

Hassan, M., Shaffril, H., Shahkat, M., Samah, B., \& Ramli, N. (2010). Agriculture Communication in Malaysia: The Current Situation. American Journal of Agricultural and Biological Sciences, 5(3), 389-396.

Holz-Clause, M., \& Jost, M. (1995). Using focus groups to check youth perceptions of agriculture. Journal of Extension [On-line], 33(3).

Ismail, M., Alias, S. N., \& Rasdi, R. M. (2015). Community as stakeholder of the corporate social responsibility programme in Malaysia: Outcomes in community development. Social Responsibility Journal, 11(1), 109-130. doi:https://doi.org/10.1108/SRJ-05-2013-0053

Jaapar, A., Salleh, S., Mahdzar, M., \& Rahim, A. (2021). The blueprint of pre-higher education program: a platform to uplift the B40 economic position through Islamic social finance. (pp. 246-259). Routledge. doi:https://doi.org/10.4324/9781003050209

Kuh, G. (2001). Assessing what really matters to student learning: Inside the National Survey of Student Engagement. Change, 33(3), 10-17, 66.

Margaret, A., \& Ghani, M. Z. (2008). Pelajar Pintar Cerdas dan Masalah yang Dihadapi. Digest Pendidik, 8(1), 8-13.

McKinney, A., Carlson, K., Mecham, R., D'Angelo, N., \& Connerley, M. (2003). Recruiters use of GPA in initial screening decisions: Higher GPAs don't always make the cut. Personnel Psychology, 56(4), 823-845.

Zain, M., \& Mohammad, R. (2007). CSR in Malaysia: The Dawn of a New Beginning. University Publication Centre (UPENA).

Muhammad, M., Ismail, A., \& Rak, A. (2013). Competency of agriculture graduates in Malaysian public Universities. International Journal of Enhanced Research In Educational Development, 1(1). 
Musa, S., Shah, J., \& Haris, N. (2020). Empowering Youth in Agriculture :Lesson for Malaysia. In Human Resources Development in Malaysia: Youth and Adult Strategic Partnerships. Universiti Putra Malaysia Press.

Nations, T. U. (2015). Transforming our world: the 2030 Agenda for Sustainable Development. The United Nations.

Noraniza, Y. (2016). Analysis on cost and profit in farming activity in Malaysia. Modern Accounting and Auditing, 12(4), 183-207.

Oduro-ofori, E., Prince, A. A., \& Elfreda, A. (2014). Effects Of Education On The Agricultural Productivity Of Farmers In The Offinso Municipality. International Journal of Development Research I, 4(9), 1951-1960.

Omar, M., Bakar, A., \& Rashid, M. A. (2012). Employability skill acquisition among malaysian community college students. Journal of Social Sciences, 8(3), 472-478.

Organization, I. L. (2015). Youth employment crisis easing but far from over. (International Labour Organization) Retrieved from http://www.ilo.org/global/about-the-ilo/ newsroom/news/WCMS_412014/lang-en/index.htm

Pan, Y., \& Lee, L. (2011). Academic performance and perceived employability of graduate students in business and management: An analysis of nationwide graduate destination survey. Procedia-Social and Behavioral Sciences, 25, 91-103.

Pinto, L., \& Ramalheira, D. (2017). Perceived employability of business graduates: The effect of academic performance and extracurricular activities. Journal of Vocational Behavior, 99, 165-178.

Plantan, S. (2013). Universities as sites of citizenship and civic responsibility. 1-28.

Sani, N. S., Shamsuddin, I. I., Sahran, S., Rahman, A. H., \& Muzaffar, E. N. (2018). Redefining selection of features and classification algorithms for room occupancy detection. IJASEIT, 8, 1486-1493.

Sibhatu, K., \& Qaim, M. (2016). Farm production diversity and dietary quality: Linkages and measurement issues. GlobalFood Discussion Paper 80. Goettingen.

Surridge, I. (2009). Accounting and finance degrees: Is the academic performance of placement students better? Accounting Education: An International Journal, 18(4-5), 471-485. 